\title{
Renal microvascular oxygen tension during hyperoxia and acute hemodilution assessed by phosphorescence quenching and excitation with blue and red light \\ Tension d'oxygène microvasculaire rénal pendant l'hyperoxie et l'hémodilution aiguë évaluée par désactivation de la phosphorescence et excitation avec de la lumière bleue et rouge
}

\author{
Kyle Chin, BMSc • Melina P. Cazorla-Bak, BVSc $\cdot$ Elaine Liu, MD $\cdot$ Linda Nghiem, RVT, \\ RLAT • Yanling Zhang, MD, PhD • Julie Yu, MD • David F. Wilson, PhD • \\ Sergei A. Vinogradov, PhD • Richard E. Gilbert, MD, PhD • Kim A. Connelly, MD, PhD • \\ Roger G. Evans, PhD • Andrew J. Baker, MD • C. David Mazer, MD • \\ Gregory M. T. Hare, MD, PhD
}

Received: 31 May 2020/Revised: 5 August 2020/Accepted: 14 August 2020/Published online: 10 November 2020

(C) Canadian Anesthesiologists' Society 2020

\begin{abstract}
Purpose The kidney plays a central physiologic role as an oxygen sensor. Nevertheless, the direct mechanism by which this occurs is incompletely understood. We measured renal microvascular partial pressure of oxygen $\left(\mathrm{P}_{k} \mathrm{O}_{2}\right)$ to determine the impact of clinically relevant conditions that acutely change $\mathrm{P}_{k} \mathrm{O}_{2}$ including hyperoxia and hemodilution.
\end{abstract}

Kyle Chin and Melina P. Cazorla-Bak contributed equally to this manuscript.

K. Chin, BMSc · E. Liu, MD

Department of Anesthesia, St. Michael's Hospital, 30 Bond

Street, Toronto, ON M5B 1W8, Canada

M. P. Cazorla-Bak, BVSc

Department of Anesthesia, St. Michael's Hospital, 30 Bond Street, Toronto, ON M5B 1W8, Canada

Department of Physiology, University of Toronto, Toronto, ON, Canada

L. Nghiem, RVT, RLAT · Y. Zhang, MD, PhD

Keenan Research Centre for Biomedical Science in the Li Ka Shing Knowledge Institute, St. Michael's Hospital, Toronto, ON, Canada

J. Yu, MD

Deaprtment of Anesthesia and Perioperative Medicine, Western University, London, ON, Canada
Methods We utilized two-wavelength excitation (red and blue spectrum) of the intravascular phosphorescent oxygen sensitive probe Oxyphor PdG4 to measure renal tissue $\mathrm{PO}_{2}$ in anesthetized rats (2\% isoflurane, $n=6)$ under two conditions of altered arterial blood oxygen content $\left(\mathrm{C}_{a} \mathrm{O}_{2}\right)$ : 1) hyperoxia (fractional inspired oxygen 21\%, 30\%, and $50 \%$ ) and 2) acute hemodilutional anemia (baseline, 25\% and $50 \%$ acute hemodilution). The mean arterial blood pressure (MAP), rectal temperature, arterial blood gases (ABGs), and chemistry (radiometer) were measured under each condition. Blue and red light enabled measurement of

D. F. Wilson, $\mathrm{PhD} \cdot \mathrm{S}$. A. Vinogradov, $\mathrm{PhD}$

Department of Biochemistry and Biophysics, School of Medicine, University of Pennsylvania, Philadelphia, PA, USA

R. E. Gilbert, MD, PhD

Keenan Research Centre for Biomedical Science in the Li Ka Shing Knowledge Institute, St. Michael's Hospital, Toronto, ON, Canada

Division of Endocrinology, Department of Medicine, St. Michael's Hospital, University of Toronto, Toronto, ON, Canada

K. A. Connelly, MD, PhD

Department of Physiology, University of Toronto, Toronto, ON, Canada

Keenan Research Centre for Biomedical Science in the Li Ka Shing Knowledge Institute, St. Michael's Hospital, Toronto, ON, Canada 
$\mathrm{P}_{k} \mathrm{O}_{2}$ in the superficial renal cortex and deeper cortical and medullary tissue, respectively.

Results $\mathrm{P}_{k} \mathrm{O}_{2}$ was higher in the superficial renal cortex ( $\sim 60 \mathrm{mmHg}$, blue light) relative to the deeper renal cortex and outer medulla $(\sim 45 \mathrm{mmHg}$, red light). Hyperoxia resulted in a proportional increase in $\mathrm{P}_{k} \mathrm{O}_{2}$ values while hemodilution decreased microvascular $\mathrm{P}_{k} \mathrm{O}_{2}$ in a linear manner in both superficial and deeper regions of the kidney. In both cases (blue and red light), $\mathrm{P}_{k} \mathrm{O}_{2}$ correlated with $\mathrm{C}_{a} \mathrm{O}_{2}$ but not with MAP.

Conclusion The observed linear relationship between $\mathrm{C}_{a} \mathrm{O}_{2}$ and $\mathrm{P}_{k} \mathrm{O}_{2}$ shows the biological function of the kidney as a quantitative sensor of anemic hypoxia and hyperoxia. A better understanding of the impact of changes in $\mathrm{P}_{k} \mathrm{O}_{2}$ may inform clinical practices to improve renal oxygen delivery and prevent acute kidney injury.

\section{Résumé}

Objectif Les reins jouent un rôle physiologique central en tant que détecteurs d'oxygène. Cependant, le mécanisme direct de ce rôle n'est pas complètement compris. Nous avons mesuré la pression partielle d'oxygène microvasculaire rénal $\left(\mathrm{P}_{k} \mathrm{O}_{2}\right)$ afin de déterminer l'impact de conditions pertinentes d'un point de vue clinique qui modifient de façon aiguë la $\mathrm{P}_{k} \mathrm{O}_{2}$, y compris l'hyperoxie et l'hémodilution.

Méthode Nous avons utilisé l'excitation à deux longueurs d'onde (spectres rouge et bleu) de la sonde phosphorescente, sensible à l'oxygène, intravasculaire Oxyphor PdG4 afin de mesurer la $\mathrm{PO}_{2}$ dans le tissu rénal de rats sous anesthésie (isoflurane $2 \%, n=6$ ) dans deux conditions de contenu en oxygène du sang artériel $\left(\mathrm{C}_{a} \mathrm{O}_{2}\right)$ altéré : 1) hyperoxie (fraction d'oxygène inspiré $21 \%, 30 \%$ et $50 \%$ ) et 2) anémie par hémodilution aigué (valeurs de base, hémodilution aiguë $25 \%$ et $50 \%$ ). La tension artérielle moyenne (TAM), la température rectale, les gaz sanguins artériels et la chimie (radiomètre) ont été mesurés dans chacune des conditions. Les lumières bleue et rouge ont permis de mesurer la $\mathrm{P}_{k} \mathrm{O}_{2}$ dans le cortex rénal superficiel et les tissus cortical et médullaire plus profonds, respectivement.

Résultats $\mathrm{La} \mathrm{P}_{k} \mathrm{O}_{2}$ était plus elevée dans le cortex rénal superficiel ( $\sim 60 \mathrm{mmHg}$, lumière bleue) comparativement au cortex rénal plus profond et à la zone médullaire extérieure $(\sim 45 \mathrm{mmHg}$, lumière rouge). L'hyperoxie a entraîné une augmentation proportionnelle des valeurs de $\mathrm{P}_{k} \mathrm{O}_{2}$, alors que l'hémodilution a diminué la $\mathrm{P}_{k} \mathrm{O}_{2}$ microvasculaire de façon linéaire tant dans les régions rénales superficielles que plus profondes. Dans les deux cas (lumières bleue et rouge), la $\mathrm{P}_{k} \mathrm{O}_{2}$ était corrélée au $\mathrm{C}_{a} \mathrm{O}_{2}$ mais pas à la TAM.

Conclusion La relation linéaire observée entre le $\mathrm{C}_{a} \mathrm{O}_{2}$ et la $\mathrm{P}_{k} \mathrm{O}_{2}$ montre la fonction biologique du rein en tant que détecteur quantitatif de l'hypoxie anémique et de l'hyperoxie. Une meilleure compréhension de l'impact des changements de la $\mathrm{P}_{k} \mathrm{O}_{2}$ pourrait guider les pratiques cliniques afin d'améliorer la distribution d'oxygène aux reins et prévenir l'insuffisance rénale aiguë:

Keywords anemia $\cdot$ renal oxygen sensing $\cdot \mathrm{CaO}_{2}$. microvascular $\mathrm{PO}_{2}$
Division of Cardiology, Department of Medicine, St. Michael's Hospital, University of Toronto, Toronto, ON, Canada

R. G. Evans, PhD

Cardiovascular Disease Program, Biomedicine Discovery Institute and Department of Physiology, Monash University, Melbourne, Australia

\section{A. J. Baker, MD}

Department of Anesthesia, St. Michael's Hospital, 30 Bond Street, Toronto, ON M5B 1W8, Canada

Keenan Research Centre for Biomedical Science in the Li Ka Shing Knowledge Institute, St. Michael's Hospital, Toronto, ON, Canada

Institute of Medical Science, University of Toronto, Toronto, ON, Canada

C. David Mazer, MD

Department of Anesthesia, St. Michael's Hospital, 30 Bond

Street, Toronto, ON M5B 1W8, Canada
Department of Physiology, University of Toronto, Toronto, ON, Canada

Institute of Medical Science, University of Toronto, Toronto, ON, Canada

G. M. T. Hare, MD, PhD ( $\square)$

Department of Anesthesia, St. Michael's Hospital, 30 Bond Street, Toronto, ON M5B 1W8, Canada

e-mail: greg.hare@unityhealth.to

Department of Physiology, University of Toronto, Toronto, ON, Canada

Keenan Research Centre for Biomedical Science in the Li Ka Shing Knowledge Institute, St. Michael's Hospital, Toronto, ON, Canada 


\section{Introduction}

The kidney is the body's chief "blood oxygen content sensor". This contributes to its roles as a regulator of integrated physiologic responses to anemia ${ }^{1}$ and the major source of systemic erythropoietin (EPO) production. ${ }^{2-4}$ Nevertheless, our understanding of the mechanisms by which it achieves this function remains incomplete. We, and others, have provided evidence that the kidney accurately senses blood oxygen content $\left(\mathrm{C}_{\mathrm{a}} \mathrm{O}_{2}\right)$ and converts this signal into a detectable level of microvascular kidney partial pressure of oxygen $\left(\mathrm{P}_{\mathrm{k}} \mathrm{O}_{2}\right){ }^{2,5-7}$ This mechanism allows cells within the kidney to respond to a specific microvascular $\mathrm{P}_{\mathrm{k}} \mathrm{O}_{2}$ as renal and systemic oxygen delivery change under varying conditions. In addition, this mechanism allows local cells to respond and alter expression of hypoxia-inducible genes, including those that synthesize EPO. ${ }^{3,4}$ Furthermore, this detection of $\mathrm{P}_{\mathrm{k}} \mathrm{O}_{2}$ may also trigger afferent signals, via the renal nerves, to initiate additional adaptive integrative physiologic changes that maintain overall oxygen homeostasis. ${ }^{1}$ One of the important concepts regarding tissue oxygen sensing is that, while oxygen is not the most soluble of biological gases, it nevertheless travels rapidly down concentration gradients across tissues and into cells. ${ }^{8,9}$ As such, oxygen is not impacted by anatomical divisions within organs; it does not differentiate between renal cortex or medulla, other than by local aspects of metabolic supply (perfusion) and demand (cellular metabolic requirement) and by vascular anatomy. ${ }^{10-12}$

The anatomy and physiology of the kidney reflect its multiple functions including waste removal, fluid and electrolyte homeostasis, and erythrogenesis. To perform these functions, the kidney receives $25 \%$ of the cardiac output and consumes about $20 \%$ of global oxygen delivery. The functional unit of the kidney is the nephron, largely defined by the filtering glomeruli, the reabsorbing and secreting tubules and vascularization by a complex blood supply. Active resorption of vital nutrients, including sodium, is a function of the cortex (proximal convoluted tubule) and outer medulla (thick ascending loop of Henle). Water resorption is largely a function of the strong sodium concentration gradient established in the medulla. Among the multiple endocrine functions of the kidney, erythrogenesis is regulated by hypoxic induction of EPO production and secretion from cells strategically located near the cortical medullary junction. ${ }^{13,14}$

In the current study, we utilized a dual light wavelength approach to measuring superficial cortical (blue light) and deeper renal cortical and medullary $\mathrm{P}_{\mathrm{k}} \mathrm{O}_{2}$ (red light) under different conditions of renal oxygen delivery, using phosphorescence quenching. We hypothesized that the physiology of renal oxygenation is set up in such a way that
$\mathrm{P}_{\mathrm{k}} \mathrm{O}_{2}$ is dependent on $\mathrm{C}_{\mathrm{a}} \mathrm{O}_{2}$ and that both superficial and deeper renal $\mathrm{P}_{\mathrm{k}} \mathrm{O}_{2}$ would be different in response to changes in $\mathrm{C}_{\mathrm{a}} \mathrm{O}_{2}$ induced by hyperoxia (which increases $\mathrm{C}_{\mathrm{a}} \mathrm{O}_{2}$ ) and hemodilutional anemia (which decreases $\mathrm{C}_{\mathrm{a}} \mathrm{O}_{2}$ ).

\section{Methods}

\section{Animal model}

All experimental protocols were approved by the Animal Care and Use Committee at St. Michael's Hospital (Toronto, ON, Canada) and conducted in accordance with the Canadian Council on Animal Care and ARRIVE-2 guidelines. Male Sprague Dawley rats (Charles River) were utilized for the experiments $(n=6$; body weight $=400-500 \mathrm{~g}$ ). Animals were housed in groups of two in standard research cages with species-appropriate enrichment. They had access to food and water ad libitum in a pathogen-free facility with a 12:12 hr light-dark cycle. After arrival to the research facility, the rats were allowed a one-week acclimation period before experiments were performed.

In spontaneously breathing rats, anesthesia was induced within an inhalation chamber with $4 \%$ isoflurane. Anesthesia was then maintained via tracheostomy with $1.5-2.0 \%$ isoflurane, initially in $21 \% \mathrm{O}_{2}$ at a total flow rate of $2 \mathrm{~L} \cdot \mathrm{min}^{-1}$ The tail vein and tail artery were cannulated to allow infusion of the hemodilution solutions, measurement of mean arterial pressure (MAP), and drawing of arterial blood for blood oximetry and chemistry (ABL 800 Flex, Radiometer Canada, London, ON, Canada). Heart rate (HR) was measured with electrocardiogram electrodes and the rectal temperature was monitored. A thermoregulatory heating pad was used to maintain rectal temperatures near $37^{\circ} \mathrm{C}$. A computerized data-acquisition system (PowerLab AD Instruments Inc., Colorado Springs, CO, USA) was used to continually monitor MAP, HR, and rectal temperature.

\section{Hyperoxia protocol}

Rats underwent spontaneous ventilation at three levels of fractional inspired oxygen $\left(\mathrm{F}_{\mathrm{I}} \mathrm{O}_{2}\right): 21 \%$ (baseline), 30\%, and $50 \%$, for $20 \mathrm{~min}$ each. At each level of inspired oxygen, three one-minute periods of measurement of microvascular $\mathrm{P}_{\mathrm{k}} \mathrm{O}_{2}$ were performed in sequence utilizing: 1) red wavelength light-emitting diode (LED, $\left.\lambda_{\max }=635 \mathrm{~nm}\right)$;2) blue wavelength $\operatorname{LED}\left(\lambda_{\max }=450 \mathrm{~nm}\right)$ and finally; 3 ) red laser light $\left(\lambda_{\max }=635 \mathrm{~nm}\right)$, according to the methods outlined below. Arterial blood gases (ABGs) were measured at the end of each period prior to changing the $\mathrm{F}_{\mathrm{I}} \mathrm{O}_{2}$. At the end of this experiment, the $\mathrm{F}_{\mathrm{I}} \mathrm{O}_{2}$ was returned to baseline (21\%) and animals were allowed to re- 
equilibrate for $30 \mathrm{~min}$ before initiating the hemodilution protocol.

\section{Hemodilution protocol}

After re-establishing baseline conditions, a baseline ABG was taken prior to the first stage of hemodilution. Rats underwent hemodilution by replacing $25 \%$ of the estimated blood volume with hydroxyethyl starch $6 \%$ (Voluven 130/ 0.4, Fresnius Kabi, Toronto, ON, Canada). Hemodilution was performed with a push-pull infusion pump (PHD2000, Harvard Apparatus, St. Laurent, QC, Canada) to maintain a steady hemodilution rate over the ten-minute period. All fluids were warmed to $37{ }^{\circ} \mathrm{C}$ before administration. After hemodilution, arterial blood was collected for analysis of oximetry and chemistry (ABG, radiometer) into heparinized syringes. Following hemodilution, microvascular $\mathrm{P}_{\mathrm{k}} \mathrm{O}_{2}$ was measured by alternating sequentially to three different light sources in the following order: red LED then blue LED then red laser. Arterial blood oximetry and chemistry were assessed as described for the hyperoxia protocol. Subsequently, a second $25 \%$ hemodilution was performed (total 50\%) and then $\mathrm{P}_{\mathrm{k}} \mathrm{O}_{2}$ and arterial blood oximetry and chemistry were re-assessed. At the end of each experiment, animals were euthanized by isoflurane overdose and intravascular injection of T-61 euthanasia solution.

\section{Microvascular kidney oxygen measurements $\left(\mathrm{P}_{\mathrm{k}} \mathrm{O}_{2}\right)$}

Microvascular kidney $\mathrm{P}_{\mathrm{k}} \mathrm{O}_{2}$ was measured in the left kidney using the phosphorescence quenching method. The intravascular oxygen probe Oxyphor PdG4 was deployed in combination with a time-domain OxyLED phosphorometer (Oxygen Enterprises Ltd., Philadelphia, PA, USA). ${ }^{8,15}$ We utilized an oximeter (OxyLED) capable of generating light at $450 \mathrm{~nm}$ (blue) and $635 \mathrm{~nm}$ (red) to excite the Soret and the Q-bands of the tetrabenzoporphyrin at the core of the probe, respectively. A common light detector was utilized to detect emitted phosphorescence following probe excitation with either blue or red light. This methodology was initially developed by Rumsey et al. ${ }^{7}$ and adapted by Johannes et al. ${ }^{5}$ to utilize excitation of phosphorescence of PdG2 (spectroscopically identical to PdG4) ${ }^{15}$ using blue and red light to discriminate between the $\mathrm{P}_{\mathrm{k}} \mathrm{O}_{2}$ measurements in the superficial renal cortex (blue light) and deeper renal cortical and medullary tissue (red light) (Fig. 1). The left kidney was exposed via a dorsal flank incision and the subjacent soft tissue and peri-renal fat were retracted. The kidney was kept within the retroperitoneal space and in the body cavity to maintain the renal temperature comparable to the core temperature. The animal was kept in a hooded

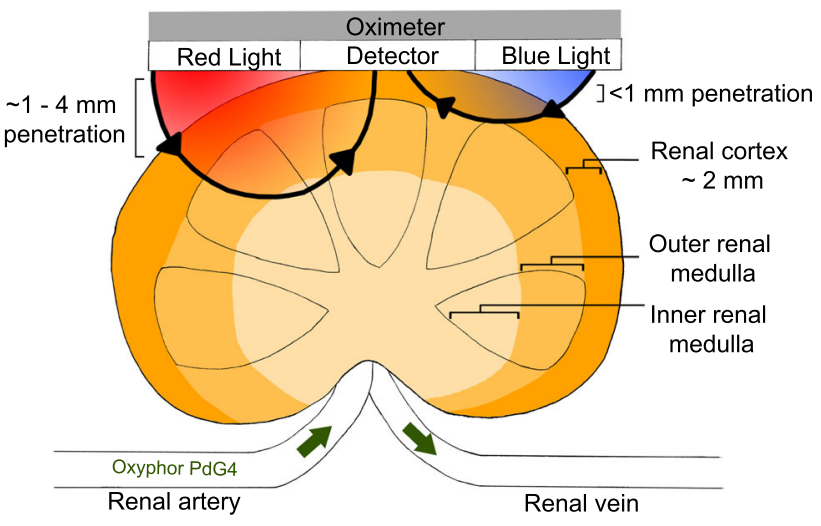

Fig. 1 A graphic representation of the method of oxygen measurement by quenching of phosphorescence of an intravascular oxyphor. The depth of penetration of blue and red light within the kidney shows the expected paths of oxyphor excitation in the superficial renal cortex (blue light) and cortex and outer medullary regions (red light).

experimental chamber to prevent ambient light from interfering with the measurements.

\section{Light excitation and detection}

Excitation light was delivered from three different sources: 1) a red LED $\left(\lambda_{\max }=635 \mathrm{~nm}\right)$, the output of which was focused on an area of $\sim 3.0 \mathrm{~mm}$ diameter on the cortical surface; 2$)$ a blue LED, $\left(\lambda_{\max }=450 \mathrm{~nm}\right)$, the output of which was focused on an area of $\sim 3.0 \mathrm{~mm}$ diameter, and 3) a red laser $\left(\lambda_{\max }=635 \mathrm{~nm}\right)$, the output of which was focused on an area $\sim 0.1 \mathrm{~mm}$ in diameter. At the red wavelength, light penetration is expected to exert its maximal energy at a depth of 1-2 $\mathrm{mm}$ and have some degree of excitation as deep as $3-4 \mathrm{~mm}$ with significant signal attenuation in proportion to the depth of tissue penetration. Thus, light measurements are taken from the microvasculature within the entire renal cortex $(\sim 2 \mathrm{~mm})$ and the underlying superficial medulla. The intensity of the red laser is higher than that of the red LED and its beam is more tightly focused. Nevertheless, as the light wavelength and $\mathrm{O}_{2}$ detection methods are similar, these methods are expected to produce comparable values. By contrast, at the blue wavelength, the depth of light penetration is expected to be attenuated to less than $1 \mathrm{~mm}$, thus providing a measurement that is essentially contained within the microcirculation of the superficial renal cortex (Fig. 1). We performed sequential measurement over the same kidney region utilizing the red LED followed by the blue LED by switching the light source through the same excitation light guide, and then conducted measurements with the red laser, with the beam targeted to the centre of the broader LED light beam. The second red laser measurements served as a positive control for the first 
red LED measure and bracketed the blue light measurement.

For all three excitation lights, the emission detecting light guide was positioned $1-2 \mathrm{~mm}$ directly above the focus of excitation and received input from the tissue at a wavelength of $813 \mathrm{~nm}$. Typically, 200 data collection cycles were averaged in a single measurement (two milliseconds), and the measurements were performed at one-second intervals. Experimental conditions were deemed acceptable with a signal to noise ratio of phosphorescence decay of greater than 2 .

Intravascular oxygen sensing probe

Prior to commencing $\mathrm{P}_{\mathrm{k}} \mathrm{O}_{2}$ measurements, Oxyphor PdG4 was injected intravenously $(450 \mu \mathrm{L}$ of $\sim 25 \mu \mathrm{M}$ solution in saline) to reach a final concentration in the blood plasma of $\sim 2 \mu \mathrm{M}$. The excitation light at 635 and $450 \mathrm{~nm}$ is relatively weakly absorbed by the endogenous tissue chromophores (e.g., hemoglobin, cytochromes, etc.). The phosphorescence of Oxyphor PdG4 $\left(\lambda_{\max }=813 \mathrm{~nm}\right)$ is attenuated by endogenous absorption even less than the excitation light, but the emitted photons generated at depths have to diffuse back to the surface to be sensed by the detector. As a result, the volume of tissue probed in such a surface excitation/emission scheme does not have strictly defined borders, although it does vary with the light transport coefficients at the wavelengths specified. It is reasonable to assume that the recorded signals are dominated by the phosphorescence originating in the upper 1-4 $\mathrm{mm}$ of tissue with tissue layers closer to the surface giving larger contribution to the signal (red light). By contrast, the recorded signals are predominantly derived from phosphorescence originating in the upper $<1 \mathrm{~mm}$ of tissue for the blue light measurements. Thus, the measurements performed in this study carry information chiefly about microvascular $\mathrm{P}_{\mathrm{k}} \mathrm{O}_{2}$ within the combined renal cortex and superficial medullary tissue (red light) or conversely from the superficial renal cortex alone (blue light).

\section{Sample size calculation}

The sample size was calculated for the primary outcome of change in $\mathrm{P}_{\mathrm{k}} \mathrm{O}_{2}$ based on preliminary data from previous experiments $^{2}$ and in accordance with the ARRIVE-2 guidelines emphasizing the goal of refining the experimental protocol to reduce animal numbers required. We estimated an expected $\mathrm{P}_{\mathrm{k}} \mathrm{O}_{2}$ difference between high and low $\mathrm{O}_{2}\left(21 \%\right.$ and $\left.50 \% \quad \mathrm{~F}_{\mathrm{I}} \mathrm{O}_{2}\right)$ and baseline vs $50 \%$ hemodilution $\mathrm{F}_{\mathrm{I}} \mathrm{O}_{2}$ to be $\sim 20 \mathrm{mmHg}$ in each case from baseline (increased in the former and decreased in the latter). Estimating a standard deviation of 5.0, and assuming a power of 0.8 and an alpha of 0.05 , our predicted sample size was six animals for each study. As a brief exposure to 30 and $50 \% \mathrm{~F}_{\mathrm{I}} \mathrm{O}_{2}$ was not expected to have a long-term impact on oxygen delivery or tissue oxygenation, we utilized the same animal for both protocols to minimize the number of animals required for these studies. Because there was a single experimental protocol, no blinding was performed.

\section{Outcome measures}

Measured outcomes in all animals include $\mathrm{P}_{\mathrm{k}} \mathrm{O}_{2}$ (measured with red LED, blue LED, and red laser), MAP, rectal temperature, $\mathrm{ABG}$ analyses and co-oximetry $(\mathrm{pH}$, arterial pressure of carbon dioxide $\left(\mathrm{P}_{\mathrm{a}} \mathrm{CO}_{2}\right)$, arterial partial pressure of oxygen $\left(\mathrm{P}_{\mathrm{a}} \mathrm{O}_{2}\right)$, bicarbonate $\left(\mathrm{HCO}_{3}\right)$, hemoglobin $(\mathrm{Hb})$, arterial blood oxygen saturation $\left(\mathrm{S}_{\mathrm{a}} \mathrm{O}_{2}\right)$, and $\left.\mathrm{C}_{\mathrm{a}} \mathrm{O}_{2}\right)$, and arterial electrolyte concentration (sodium, chloride, potassium, calcium, glucose, and lactate), all during hyperoxia and hemodilution.

\section{Statistical analysis}

Normality was tested with the Shapiro-Wilk test. Data that did not significantly violate normality were subjected to two-way analysis of variance (ANOVA) for repeated measures and post-hoc Tukey test for pairwise comparisons. Data that failed the Shapiro-Wilk test were analyzed using the Kruskal-Wallis one-way ANOVA on ranks followed by post-hoc pairwise comparisons using Dunn's method. Lines of best fit were generated by ordinary least products regression analysis. Analysis of covariance was used to determine whether these relationships differed according to the intervention (hyperoxia or hemodilution). A two-tailed $P<0.05$ was considered statistically significant. Analyses were performed using either Sigmaplot or Systat software (Systat Software Inc., San Jose, CA, USA).

\section{Results}

Physiologic parameters

Following stepwise increases in $\mathrm{F}_{\mathrm{I}} \mathrm{O}_{2}$ (hyperoxia), there were no changes in HR or MAP (Fig. 2, panels A and B). Following hemodilution, there was a significant increase in HR after $25 \%$ and $50 \%$ hemodilution, relative to baseline (Fig. 3, panel A). No statistically significant changes were observed in the MAP; however, there was a trend for MAP to decrease after $50 \%$ hemodilution (Fig. 3, panel B). Rectal temperature remained stable, near $37{ }^{\circ} \mathrm{C}$ throughout the experimental period. 

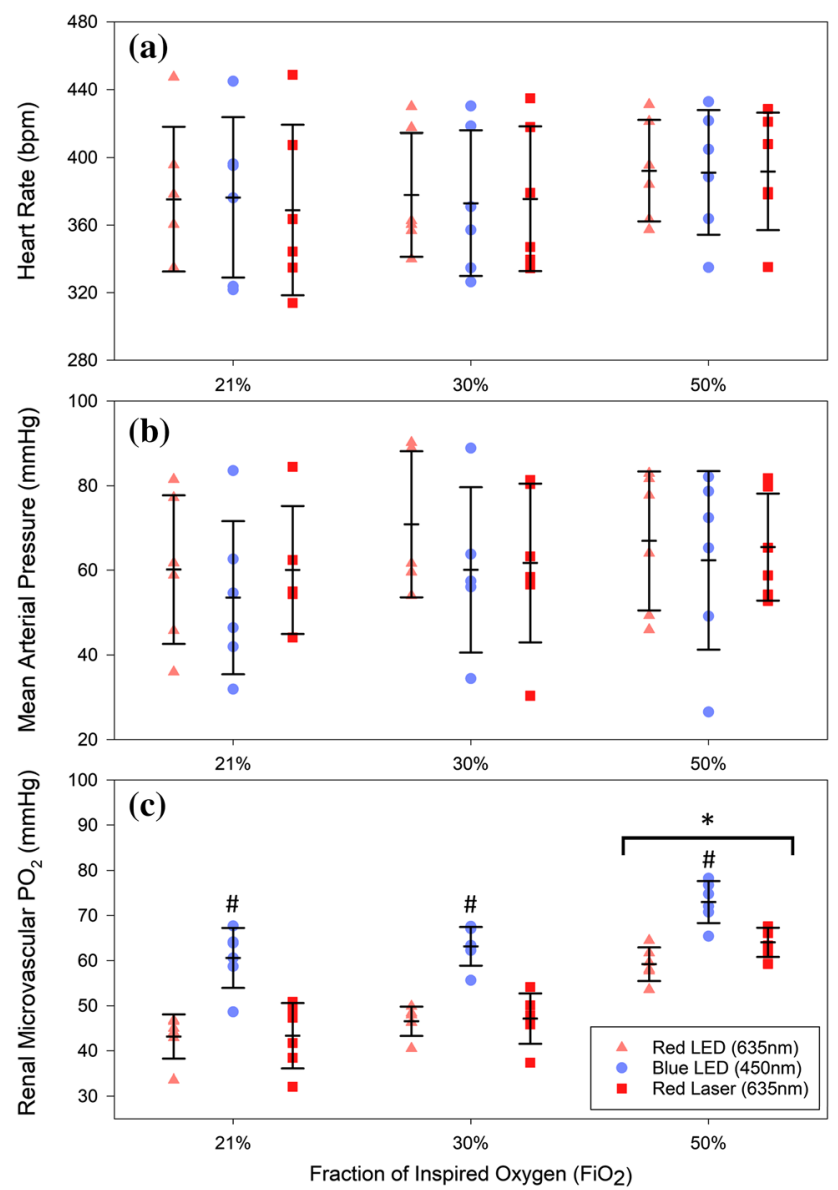

Fig. 2 Hemodynamic and microvascular kidney $\mathrm{PO}_{2} \quad\left(\mathrm{P}_{\mathrm{k}} \mathrm{O}_{2}\right)$ measurements after exposure to hypoxia. A) Heart rate, and B) mean arterial pressure (MAP) were maintained throughout the stepwise increase in the fraction of inspired oxygen $\left(\mathrm{F}_{\mathrm{I}} \mathrm{O}_{2}\right)$. C) At all three $\mathrm{F}_{\mathrm{I}} \mathrm{O}_{2}$ levels, the blue light-emitting diode (LED) measured $\mathrm{P}_{\mathrm{k}} \mathrm{O}_{2}$ significantly higher than both the red LED and red laser measurements $(\# P<0.001)$. The red LED and red laser measurements were similar at $21 \%$ and $30 \% \mathrm{~F}_{\mathrm{I}} \mathrm{O}_{2}$. The stepwise increase in $\mathrm{F}_{\mathrm{I}} \mathrm{O}_{2}$ showed expected trending of increased $\mathrm{P}_{\mathrm{k}} \mathrm{O}_{2}$. For all sources of light, the $\mathrm{P}_{\mathrm{k}} \mathrm{O}_{2}$ at $50 \%$ was significantly higher than both $21 \%$ and $30 \%(* P<0.002)$. No significant difference was observed between $\mathrm{F}_{\mathrm{I}} \mathrm{O}_{2}$ at $21 \%$ and $30 \%(n=6)$.

\section{Arterial blood gas analysis}

The blood oximetry data showed the expected changes in $\mathrm{P}_{\mathrm{a}} \mathrm{O}_{2}, \mathrm{Hb}$, and $\mathrm{C}_{\mathrm{a}} \mathrm{O}_{2}$ during hyperoxia and hemodilution (Tables 1 and 2). With increasing $\mathrm{F}_{\mathrm{I}} \mathrm{O}_{2}$, there was an expected stepwise increase in $\mathrm{P}_{\mathrm{a}} \mathrm{O}_{2}$ and arterial blood $\mathrm{Hb}$ saturation $\left(\mathrm{S}_{\mathrm{a}} \mathrm{O}_{2}\right)$, and a slight increase in $\mathrm{C}_{\mathrm{a}} \mathrm{O}_{2}$, as dictated by the formula: $\mathrm{C}_{\mathrm{a}} \mathrm{O}_{2}=\left(1.34 * \mathrm{Hb} * \mathrm{~S}_{\mathrm{a}} \mathrm{O}_{2} / 100\right)+(0.0031$ $\left.* \mathrm{P}_{\mathrm{a}} \mathrm{O}_{2}\right)(P<0.05)$. All other parameters did not change as $\mathrm{F}_{\mathrm{I}} \mathrm{O}_{2}$ increased from $21 \%$ to $30 \%$ to $50 \%$ (Table 1 ). Following hemodilution, there was an expectant stepwise decrease in blood hemoglobin concentration and $\mathrm{C}_{\mathrm{a}} \mathrm{O}_{2}(P<$
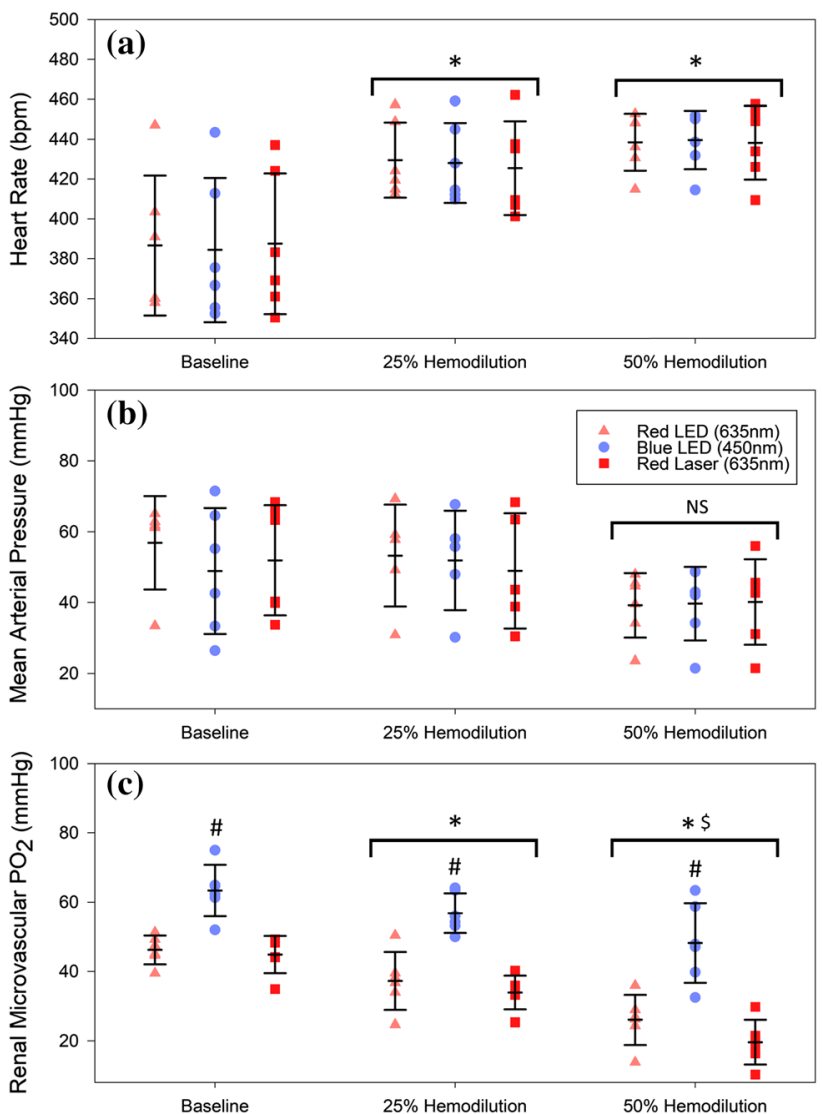

Fig. 3 Hemodynamic and $\mathrm{P}_{\mathrm{k}} \mathrm{O}_{2}$ measurements after exposure to hemodilution. A) Heart rate and B) mean arterial pressure (MAP) were maintained throughout the hemodilutions. C) At control and the two hemodilution levels, the blue light-emitting diode (LED) measured significantly higher kidney tissue oxygen tension $\left(\mathrm{P}_{\mathrm{k}} \mathrm{O}_{2}\right)$ than both the red LED and red laser measurements ( $\# P<0.001)$. The red LED and red laser measurements were similar during control and $25 \%$ hemodilution. At $50 \%$ hemodilution, the red laser $\mathrm{P}_{\mathrm{k}} \mathrm{O}_{2}$ was significantly lower than the red LED $(\$ P=0.023)$. For all light sources there was a progressive decrease in $\mathrm{P}_{\mathrm{k}} \mathrm{O}_{2}$ after $25 \%$ and $50 \%$ hemodilution relative to baseline $(* P<0.029)(n=6)$.

0.001 ). As hydroxyethyl starch is constituted in $0.9 \% \mathrm{w} / \mathrm{v}$ $\mathrm{NaCl}$, an increase in plasma chloride concentration was observed $(P=0.025)$; plasma $\mathrm{HCO}_{3}$ decreased $(P=0.03)$ and lactate increased slightly after 50\% hemodilution $(P=$ 0.006) (Table 2). Serum glucose decreased after hyperoxia and 50\% hemodilution $(P<0.05)$ There were no statistically significant differences in other parameters over time (Table 2).

Kidney microvascular $\mathrm{P}_{\mathrm{k}} \mathrm{O}_{2}$ values

At baseline, the $\mathrm{P}_{\mathrm{k}} \mathrm{O}_{2}$ values obtained with the red light (LED, laser) were comparable to those reported previously ${ }^{1}$ (Figs 2 and 3, panel C). In all conditions, the $\mathrm{P}_{\mathrm{k}} \mathrm{O}_{2}$ values obtained with the blue light were higher than 
Table 1 Arterial blood gas and co-oximetry data

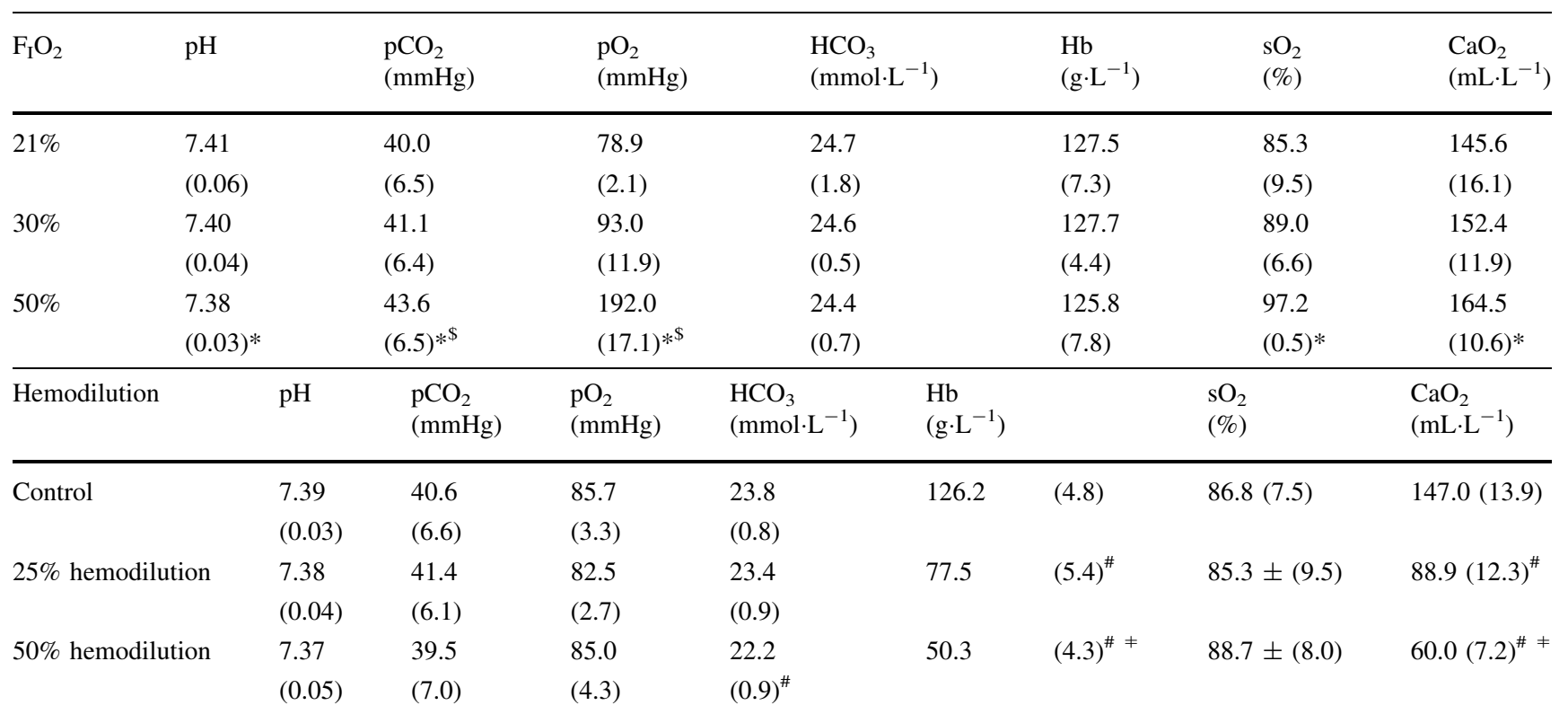

$* P<0.05$ vs $21 \% \mathrm{~F}_{\mathrm{I}} \mathrm{O}_{2} . \$ P<0.05$ vs $30 \% \mathrm{~F}_{\mathrm{I}} \mathrm{O}_{2}$.

$\# P<0.05$ vs control; $\neq P<0.05$ vs $25 \%$ hemodilution.

Values are mean (standard deviation)

$\mathrm{C}_{\mathrm{a}} \mathrm{O}_{2}=$ conditions of altered blood oxygen content; $\mathrm{Hb}=$ concentration of hemoglobin $; \mathrm{F}_{1} \mathrm{O}_{2}=$ fractional inspired oxygen; $\mathrm{HCO}_{3}=$ bicarbonate; $\mathrm{pO}_{2}=$ partial oxygen pressure $; \mathrm{pCO}_{2}=$ partial pressure of carbon dioxide; $\mathrm{sO}_{2}=$ sulfur dioxide.

those generated using red light (Figs 2 and 3). In all cases, the microvascular renal $\mathrm{P}_{\mathrm{k}} \mathrm{O}_{2}$ values were comparable when taken using the red LED, prior to blue LED measurement, and those of the red laser which were taken immediately after the blue LED measurement. This sequence showed the stability of the red light measurements and that the $\mathrm{P}_{\mathrm{k}} \mathrm{O}_{2}$ values were comparable when measured using excitation red light delivered by differing light intensities and beam widths.

During hyperoxia exposure, renal kidney tissue $\mathrm{P}_{\mathrm{k}} \mathrm{O}_{2}$ increased with each increase in the level of $\mathrm{F}_{\mathrm{I}} \mathrm{O}_{2}$ as measured following oxyphor excitation by both red and blue light (Fig. 2, panel C). During sequential hemodilution, the $\mathrm{P}_{\mathrm{k}} \mathrm{O}_{2}$ decreased in proportion to the reduction in blood hemoglobin concentration and $\mathrm{C}_{\mathrm{a}} \mathrm{O}_{2}$, in a stepwise manner, despite a relatively constant $\mathrm{P}_{\mathrm{a}} \mathrm{O}_{2}$ (Fig. 3, panel C). The red LED and laser values were comparable when measured before and after the blue LED values.

Assessment of different correlations between physiologic parameters showed that renal microvascular $\mathrm{P}_{\mathrm{k}} \mathrm{O}_{2}$, measured with blue or red light, did not correlate with MAP $\left(\mathrm{r}^{2}=0.08\right.$ and 0.005 , respectively) (Fig. 4, panels A). Nevertheless, values for microvascular renal
$\mathrm{P}_{\mathrm{k}} \mathrm{O}_{2}$ obtained with blue $v s$ red LED were closely correlated $\left(r^{2}=0.78\right)$ (Fig. 4, panel B).

Assessment of the relationships between microvascular renal $\mathrm{P}_{\mathrm{k}} \mathrm{O}_{2}$ utilizing blue and red light showed significant correlations with $\mathrm{C}_{\mathrm{a}} \mathrm{O}_{2}$ (Fig. 5). $\quad \mathrm{P}_{\mathrm{k}} \mathrm{O}_{2}$ was closely correlated with $\mathrm{C}_{\mathrm{a}} \mathrm{O}_{2}$ both for blue $\left(\mathrm{r}^{2}=0.56\right)$ and red $\left(\mathrm{r}^{2}\right.$ $=0.69)$ light, representing measurements from the superficial renal cortex and deep renal cortex and outer medulla, respectively. The relationships between these variables did not vary significantly between the two interventions (Fig. 5).

We hypothesized that a change in $\mathrm{C}_{\mathrm{a}} \mathrm{O}_{2}$ with hemodilution would follow a different relationship than hyperoxia. Nevertheless, our analysis failed to detect any significant differences. Therefore, while there is a difference between red and blue light, we found a linear relationship between hyperoxia and hemodilution. We ran the regression analyses for the individual interventions, and found the following results for hyperoxia (red LED $\mathrm{r}^{2}=$ $0.232, P=0.07$, blue LED $r^{2}=0.343, P=0.02$, red laser $r^{2}$ $=0.051, P=0.42$ ) and for hemodilution (red LED $\mathrm{r}^{2}=$ $0.687, P<0.001$, blue LED $r^{2}=0.469, P=0.005$, red laser $\left.\mathrm{r}^{2}=0.847, P<0.001\right)$. Thus, as predicted by the data in the scatterplots, the relationships were more robust for hemodilution than for hyperoxia. Nevertheless, a 
Table 2 Arterial blood electrolyte data

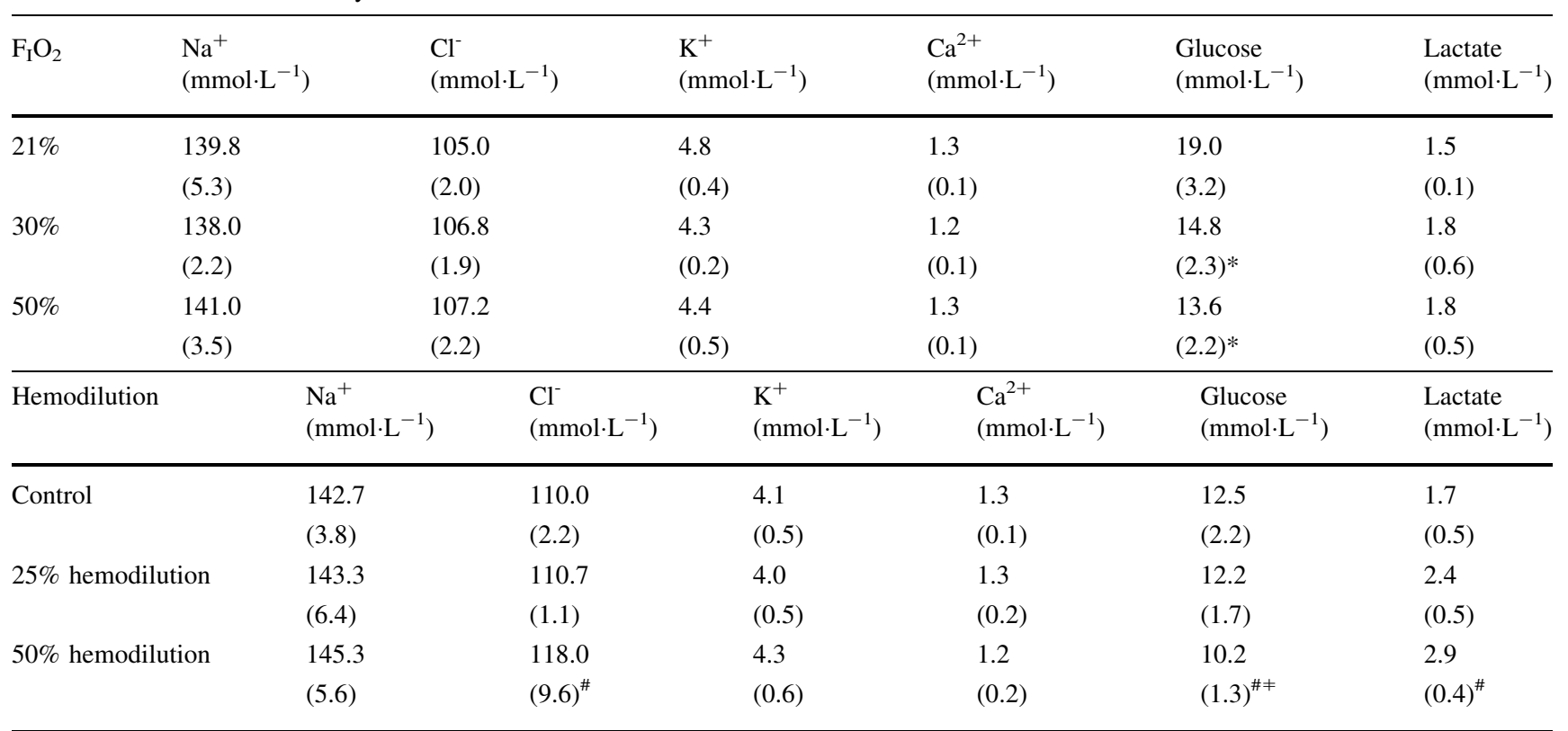

${ }^{*} P<0.05$ vs $21 \% \mathrm{~F}_{\mathrm{I}} \mathrm{O}_{2},{ }^{\#} P<0.05$ vs control; ${ }^{*} P<0.05$ vs $25 \%$ hemodilution.

Values are mean (standard deviation); $\mathrm{F}_{\mathrm{I}} \mathrm{O}_{2}=$ fractional inspired oxygen.

significant relationship was observed for hyperoxia with the blue LED and a strong tendency was seen with the red LED.

\section{Discussion}

We show that $\mathrm{P}_{\mathrm{k}} \mathrm{O}_{2}$, in both superficial and deeper layers of the kidney, varies in a linear manner with $\mathrm{C}_{\mathrm{a}} \mathrm{O}_{2}$. Importantly, a single relationship can adequately explain the variation of $\mathrm{P}_{\mathrm{k}} \mathrm{O}_{2}$ with $\mathrm{C}_{\mathrm{a}} \mathrm{O}_{2}$ during hyperoxia and hemodilution. This allows us to attribute the oxygen sensing capacity of the kidney to an ability to translate changes in $\mathrm{C}_{\mathrm{a}} \mathrm{O}_{2}$ to changes in kidney $\mathrm{P}_{\mathrm{k}} \mathrm{O}_{2}$. The impact of hyperoxia (relatively high $\mathrm{C}_{\mathrm{a}} \mathrm{O}_{2}$ ) and anemia (low $\mathrm{C}_{\mathrm{a}} \mathrm{O}_{2}$ ) on changes in $\mathrm{P}_{\mathrm{k}} \mathrm{O}_{2}$ showed a similar linear relationship, supporting the hypothesis that $\mathrm{C}_{\mathrm{a}} \mathrm{O}_{2}$ is biologically sensed. The lack of correlation between MAP and arterial $\mathrm{P}_{\mathrm{a}} \mathrm{O}_{2}$ and renal microvascular $\mathrm{P}_{\mathrm{k}} \mathrm{O}_{2}$ supports the finding that $\mathrm{C}_{\mathrm{a}} \mathrm{O}_{2}$ is an important physiologic parameter that regulates renal $\mathrm{P}_{\mathrm{k}} \mathrm{O}_{2}$.

Our observations are in accord with traditional studies assessing increased expression of renal EPO following exposure to both hypoxia and anemia. ${ }^{3,4}$ Recent observations in humans regarding the control of EPO release from the kidney support the concept that $\mathrm{C}_{\mathrm{a}} \mathrm{O}_{2}$ and not $\mathrm{P}_{\mathrm{a}} \mathrm{O}_{2}$ is the important variable with respect to regulating EPO secretion. ${ }^{16}$ In a crossover study with human volunteers, Montero and Lundby showed that the increase in systemic EPO levels associated with a reduction of $\mathrm{C}_{\mathrm{a}} \mathrm{O}_{2}$ induced by subjects breathing low concentrations of carbon monoxide while mainlining $\mathrm{P}_{\mathrm{a}} \mathrm{O}_{2}$ above 100 mmHg was comparable to that observed by reduced $\mathrm{C}_{\mathrm{a}} \mathrm{O}_{2}$ induced by breaking a hypoxic gas mixture $\left(\mathrm{F}_{\mathrm{I}} \mathrm{O}_{2}=11 \%\right)$. Thus, the mechanisms that regulate kidney oxygenation appear to be set up in such a way that microvascular, and thus tissue $\mathrm{PO}_{2}$, is sensitive to changes in $\mathrm{C}_{\mathrm{a}} \mathrm{O}_{2}$ no matter how they are induced. ${ }^{16}$

The dominance of $\mathrm{C}_{\mathrm{a}} \mathrm{O}_{2}$ in the control of renal tissue oxygenation can be explained by available knowledge regarding oxygen transport to tissue and the incorporation of this knowledge into computational models of renal oxygen transport. It is well established that oxygen delivery to tissue is driven by the gradient between the intravascular and tissue $\mathrm{PO}_{2}{ }^{17}$ Importantly, in the kidney ${ }^{18}$ and in other vascular beds, ${ }^{17}$ oxygen diffuses from the vasculature to the tissue not only from capillaries but also from arterial vessels. Consequently, as blood flows from the main renal artery to the renal microvasculature, its oxygen content falls in proportion to the gradient between the vascular and tissue compartments. ${ }^{19}$ Some oxygen is also lost via diffusion to the veins, which are often closely associated with the arterial vessels. ${ }^{19,20}$

Factors driving renal oxygen delivery include $\mathrm{C}_{\mathrm{a}} \mathrm{O}_{2}$ and dissolved $\mathrm{O}_{2}$. The formula for $\mathrm{C}_{\mathrm{a}} \mathrm{O}_{2}$ further defines the relationship between $\mathrm{Hb}$-bound $\mathrm{O}_{2}$ and dissolved $\mathrm{O}_{2}$ in the plasma: $\mathrm{CaO}_{2}=\left(1.34 \times \mathrm{Hb} \times \mathrm{S}_{\mathrm{a}} \mathrm{O}_{2} / 100\right)+(0.0031 \times$ $\mathrm{P}_{\mathrm{a}} \mathrm{O}_{2}$ ). This formula expresses that $\mathrm{P}_{\mathrm{a}} \mathrm{O}_{2}$ (i.e., dissolved 

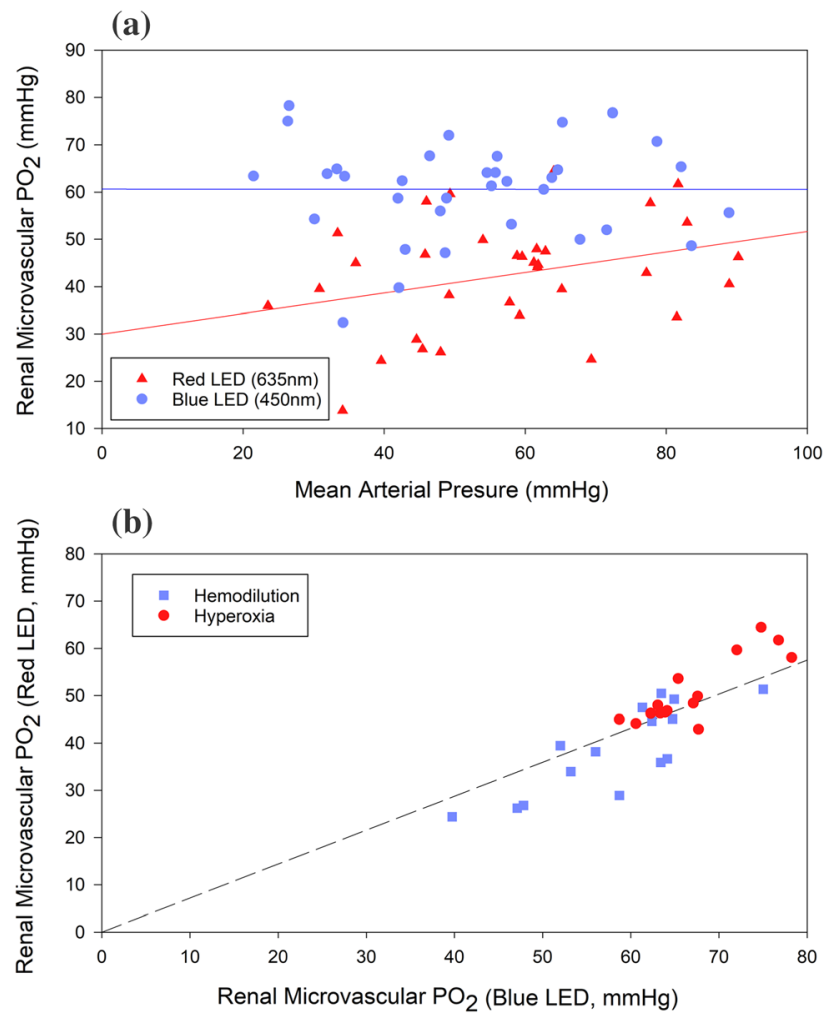

Fig. 4 Scatterplot of the relationships between $\mathrm{P}_{\mathrm{k}} \mathrm{O}_{2}$ measured using the red and blue light emitting diodes $\left(r^{2}=0.78\right)$. Data are from experiments in five rats. The $\mathrm{x}$-intercept of the line of best fit did not differ significantly from zero [point estimate (95\% confidence interval $)=1.04$ (-8.36 to 10.44$)$ but the slope was significantly less than unity $(0.71(0.56$ to 0.86$)]$. In analysis of covariance, neither the intercept $(P=0.85)$ nor the slope $(P=0.98)$ varied significantly according to the intervention (hyperoxia or hemodilution).

oxygen in plasma) only represents a minute portion of the total oxygen transported in the blood. Simplistically, oxygen carried by $\mathrm{Hb}$ represents the bulk of $\mathrm{O}_{2}$ delivered to tissues while arterial $\mathrm{P}_{\mathrm{a}} \mathrm{O}_{2}$ and microvascular renal $\mathrm{P}_{\mathrm{k}} \mathrm{O}_{2}$, represent the component of oxygen progressively released from $\mathrm{Hb}$ on route to the mitochondria of metabolically active cells. The complexity of local renal vascular-tissue oxygen gradients are not directly measured by our technique; rather, the sum effect of these local oxygen gradients are measured within a sample of renal microvasculature that directly reflects tissue $\mathrm{PO}_{2}{ }^{2}$

Simulations derived from computational models of oxygen transport predict that, under conditions where there is an increase in the fraction of inspired $\mathrm{O}_{2}$, arterial $\mathrm{PO}_{2}$ falls rapidly along the arterial tree because this condition is associated with only a small additional quantity of oxygen in the blood. Consequently, the increase in $\mathrm{C}_{\mathrm{a}} \mathrm{O}_{2}(\sim 15 \%)$ and $\mathrm{P}_{\mathrm{k}} \mathrm{O}_{2}(\sim 25 \%)$ observed with hyperoxia are relatively small in relation to the increase in $\mathrm{P}_{\mathrm{a}} \mathrm{O}_{2}(\sim 250 \%)$. Nevertheless, the changes in $\mathrm{C}_{\mathrm{a}} \mathrm{O}_{2}$ remain in proportion to the changes in renal
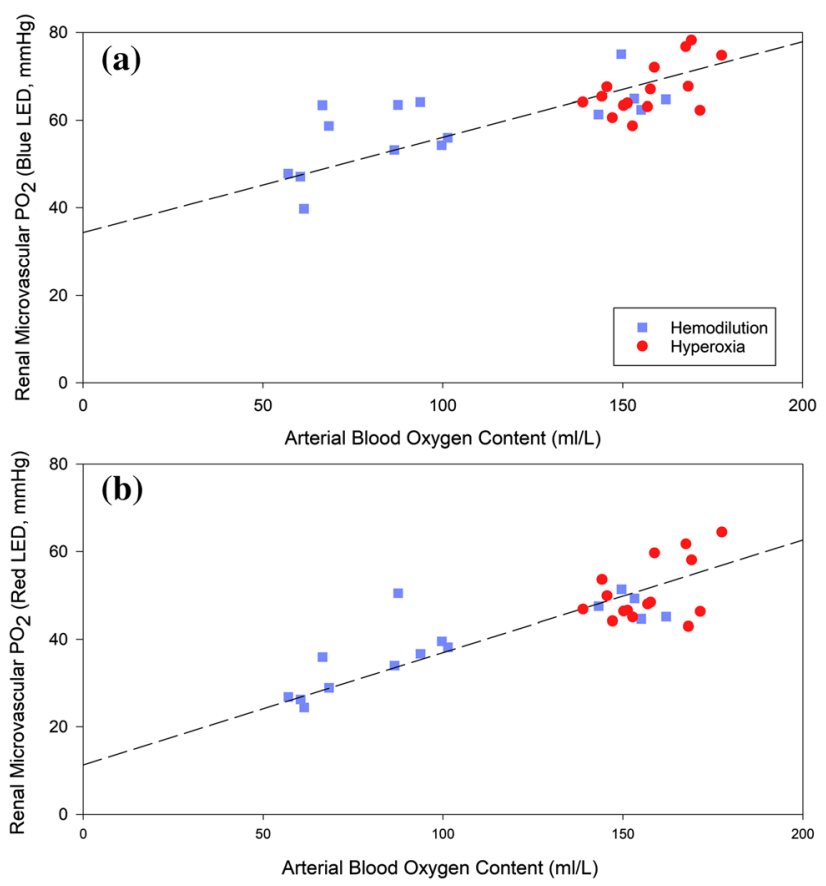

Fig. 5 Scatterplots of the relationships between arterial blood oxygen content $\left(\mathrm{C}_{\mathrm{a}} \mathrm{O}_{2}\right)$ and $\mathrm{P}_{\mathrm{k}} \mathrm{O}_{2}$ measured using either $(\mathrm{A})$ blue $\left(\mathrm{r}^{2}=0.56\right)$ or (B) red $\left(\mathrm{r}^{2}=0.69\right)$ light emitting diodes (LEDs). Data are from experiments in five rats. In analysis of covariance, neither the intercepts nor the slopes of these relationships differed significantly according to the intervention (hyperoxia or hemodilution). $P$ values for differences in intercept and slope between the two interventions were $\geq 0.13$ for both blue and red LEDs

microvascular $\mathrm{P}_{\mathrm{k}} \mathrm{O}_{2} \cdot{ }^{21,22}$ On the other hand, when $\mathrm{C}_{\mathrm{a}} \mathrm{O}_{2}$ is reduced by hemodilution by decreasing the major determinant of $\mathrm{C}_{\mathrm{a}} \mathrm{O}_{2}$ (i.e., $\mathrm{Hb}$ ), blood oxygen content is reduced by a larger proportion $(\sim 60 \%)$ as reflected by a more pronounced drop in kidney $\mathrm{P}_{\mathrm{k}} \mathrm{O}_{2}(\sim 50 \%)$. Under these conditions, oxygen diffusion from the arterial tree results in a more pronounced reduction in the $\mathrm{PO}_{2}$ of blood, as it flows to the microvasculature, compared with normal conditions. ${ }^{23}$ As we show herein, the change in $\mathrm{P}_{\mathrm{k}} \mathrm{O}_{2}$ is proportional to the change in $\mathrm{C}_{\mathrm{a}} \mathrm{O}_{2}$. The consequence of this physiologic system is that the EPO-producing cells in the kidney are in an ideal place to sense changes in $\mathrm{C}_{\mathrm{a}} \mathrm{O}_{2}$ and thus regulate red cell production in response to acute anemia. $^{2-4,13,14}$

Our findings are also consistent with the notion of a gradient in microvascular and tissue $\mathrm{PO}_{2}$ from the renal cortex to medulla, ${ }^{24}$ at least in anesthetized animals ${ }^{5,25,26}$ and humans. ${ }^{27,28}$ This gradient may be less pronounced in the absence of anesthesia. ${ }^{29}$ In the current study of anesthetized rats, we found $\mathrm{P}_{\mathrm{k}} \mathrm{O}_{2}$ measured using a red LED was systematically lower than that measured using a blue LED, likely because the red LED penetrates deeper into the tissue. ${ }^{30}$ Nevertheless, changes in $\mathrm{C}_{\mathrm{a}} \mathrm{O}_{2}$ resulted in proportionally similar changes in the two measures of 
microvascular $\mathrm{P}_{\mathrm{k}} \mathrm{O}_{2}$. We are not aware of any previous direct quantitative comparison of the relative sensitivities of kidney tissue, at various depths below the cortical surface, to changes in $\mathrm{C}_{\mathrm{a}} \mathrm{O}_{2}$. Nevertheless, our current findings are consistent with the observation of similar changes in renal cortical and medullary $\mathrm{P}_{\mathrm{k}} \mathrm{O}_{2}$ induced by hemodilution in rats, ${ }^{5}$ hypoxia in rabbits, ${ }^{31}$ and hyperoxia in sheep. ${ }^{29}$

Understanding the relationship between the physiologic function of the kidney with respect to oxygen demand and supply may help explain its role as an oxygen sensor. With respect to metabolic demand, we will focus on sodium $(\mathrm{Na})$ resorption as one of the major components of renal metabolic demand. ${ }^{14}$ The majority of filtered $\mathrm{Na}(\sim$ $65 \%$ ) is recovered in the proximal convoluted tubule within the renal cortex, powered by the sodium potassium ATPase. The next important component for Na resorption ( $\sim 25 \%$ ) occurs in the loop of Henle within the renal medulla. About half of medullary $\mathrm{Na}$ resorption occurs passively, along the generated concentration gradient, while the remaining half is absorbed via active transport in the thick ascending limb of Henle's loop (Na-K ATPase). The remaining $10 \%$ of Na resorption occurs by active transport in the distal convoluted tubule, situated adjacent to the macula densa of the glomerulus.

To optimize renal oxygen delivery, the vasculatures of the renal cortex and medulla are arranged in parallel, starting at the level of the proximal interlobular arteries. Thus, blood flow to these two vascular territories can be independently regulated. In the outer medulla, the blood supply further divides as some vasa recta capillaries form a plexus in the outer medulla while others go on to perfuse the inner medulla. Thus, there is some potential for independent regulation of perfusion of the inner and outer medulla. ${ }^{20}$

Finally, the balance of oxygen supply and demand dictate how the kidney functions as an oxygen sensor. ${ }^{14}$ The kidney is the principal regulator of erythrocyte production as a response to vascular oxygen content induced by hypoxia or anemia..$^{2-4,32,33}$ Under resting conditions, the majority of EPO-producing cells are located near the cortico-medullary junction., ${ }^{3,4}$ Nevertheless, following exposure to conditions that cause renal tissue hypoxia or molecular manipulation to simulate hypoxia, the regions in which EPO-producing cells are identified expands into the superficial renal cortex and deep medulla, ${ }^{4,13,34}$ thereby showing the capacity for rapid and profound upregulation of EPO transcription and excretion.

By utilizing characteristics of shorter wavelength blue light $v s$ longer wavelength red light, we have observed that measurements of $\mathrm{P}_{\mathrm{k}} \mathrm{O}_{2}$ are higher in the superficial renal cortex (blue light) than values obtained with more deeply penetrating red light. This finding has been previously reported utilizing stepwise progression of Clarke type microelectrodes $^{6}$ and utilizing the method of phosphorescence quenching during acute hemodilution. ${ }^{5}$ Nevertheless, a clear relationship between $\mathrm{C}_{\mathrm{a}} \mathrm{O}_{2}$ and $\mathrm{P}_{\mathrm{k}} \mathrm{O}_{2}$ was not derived by these previous studies. The difference in the values measured with blue $v s$ red light suggest that superficial blue light measures more arterialized blood from afferent arterioles as they enter the glomeruli, situated in the cortex. Conversely, red light penetrates more deeply into the renal cortex and outer renal medulla. Furthermore, the renal cortex and outer renal medulla are highly metabolic because of the metabolic activity of the proximal convoluted tubule and thick ascending loop of Henle, which both consume high amounts of oxygen. This is one of the multiple explanations for a decreased $\mathrm{P}_{\mathrm{k}} \mathrm{O}_{2}$ in the outer medulla compared with the cortex. ${ }^{11}$ The finding that $\mathrm{P}_{\mathrm{k}} \mathrm{O}_{2}$ values with blue and red light strongly correlate with one another suggests that measurement of superficial cortical or deeper cortical and medullary microvascular $\mathrm{P}_{\mathrm{k}} \mathrm{O}_{2}$ both reflect changes in blood $\mathrm{C}_{\mathrm{a}} \mathrm{O}_{2}$, in balance with local oxygen demand. The net effect reflects the balance between oxygen supply and demand.

Estimates of renal oxygen consumption and metabolic activity suggest that the proximal tubules and outer medullary thick ascending loop of Henle (mTAL) represent regions of high metabolic oxygen requirement. ${ }^{35,36}$ Furthermore, the inner renal cortex and outer renal medulla are the locations for EPO synthesis ${ }^{3,4}$ while the outer medulla is the region of the kidney most susceptible to hypoxia, in part due to relatively limited vascular supply compared with the cortex..$^{11,20}$ The disposition of the medullary vasculature (the vasa recta) in bundles leads to countercurrent oxygen exchange throughout the medulla. This results in a decreased oxygen supply in the inner renal medulla. The disposition of the vascular bundles, with respect to the mTAL and the collecting duct, results in an oxygen gradient from the bundles to these elements of the nephron, rendering them especially susceptible to hypoxia. ${ }^{11,20}$ Therefore, the renal outer medulla is at particular risk of hypoxia and hypoxic injury, as the balance of oxygen supply and demand puts this region at risk of inadequate oxygen delivery. ${ }^{35,37}$ This characteristic is precisely what renders it an efficient sentinel for the oxygenation status of the rest of the body. In fact, the medullary region is known for its capacity to rapidly upregulate hypoxia gene expression, ${ }^{2,4}$ including EPO, showing the link between low $\mathrm{C}_{\mathrm{a}} \mathrm{O}_{2}$, microvascular $\mathrm{P}_{\mathrm{k}} \mathrm{O}_{2}$, and hypoxic biological responses.

Translational implications

We have previously shown that experimental measurement of tissue oxygen tension can inform clinical decision- 
making in a number of clinical scenarios. For example: 1) anemia is associated with tissue hypoxia, ${ }^{38}$ possibly explaining the association between preoperative anemia and increased mortality ${ }^{39}$; 2) systemic $\beta$-blockade accentuates anemia-induced cerebral hypoxia, ${ }^{40-42}$ possibly explaining the increased incidence of perioperative stroke $^{43}$; 3) acute anemia worsens brain tissue hypoxia and greatly enhances the degree of brain injury, ${ }^{44}$ supporting utilization of brain $\mathrm{PO}_{2}$ monitoring to support clinical decision-making ${ }^{45}$ and potentially improving patient outcomes ${ }^{46}$; and 4 ) assessment of renal $\mathrm{P}_{\mathrm{k}} \mathrm{O}_{2}$ showed a more profound decrease following hemodilution with starch $v s$ albumin or saline, ${ }^{2}$ possibly providing a mechanistic explanation for increased renal toxicity associated with starch-based fluid resuscitation in critical care settings. ${ }^{47}$ The current study shows that microvascular renal $\mathrm{PO}_{2}$ values reflect oxygen delivery to tissues at times of reduced blood oxygen content. Clinical studies have attempted to measure renal tissue hypoxia may predict adverse outcomes, including acute kidney injury. ${ }^{28,48}$ The common goal of these approaches is to direct therapies to reduce perioperative organ injury and adverse clinical outcomes.

\section{Limitations}

There are some limitations to our current study. First, we did not measure cardiac output (CO) in this experimental data set as we have previously showed that $\mathrm{CO}$ increases following hemodilution with starch, ${ }^{2,42}$ but that changes in microvascular renal perfusion are not directly liked to these changes in $\mathrm{CO}^{2}$ Second, the effect of hyperoxia was limited because of the small increment in $\mathrm{C}_{\mathrm{a}} \mathrm{O}_{2}\left(\mathrm{P}_{\mathrm{a}} \mathrm{O}_{2}\right.$ only contributes to a small proportion of total $\mathrm{C}_{\mathrm{a}} \mathrm{O}_{2}$ ). Nevertheless, the slope of the hyperoxia effect was comparable to that of hemodilution, supporting that the impact of both hyperoxia and hemodilution were influenced by $\mathrm{C}_{\mathrm{a}} \mathrm{O}_{2}$. Third, these measurements were performed under anesthesia, which is known to impact renal oxygen delivery. ${ }^{23}$ Indeed, increased $\mathrm{F}_{\mathrm{I}} \mathrm{O}_{2}$ and hyperoxia have been shown to restore renal oxygen tension in experimental models potentially supporting the use of hyperoxia in patients under general anesthesia to preserve renal function.

\section{Perspectives and significance}

Utilizing non-invasive methods to measure microvascular renal tissue $\mathrm{P}_{\mathrm{k}} \mathrm{O}_{2}$, we have shown a linear relationship between blood oxygen content $\left(\mathrm{C}_{\mathrm{a}} \mathrm{O}_{2}\right)$ and renal tissue $\mathrm{P}_{\mathrm{k}} \mathrm{O}_{2}$. The relationship is maintained with two different excitation light wavelengths, confirming the impact of $\mathrm{C}_{a} \mathrm{O}_{2}$ in superficial (with blue light) and deeper (with red light) renal tissue. These data provide an experimental means for assessing the impact of tissue hypoxia on renal injury ${ }^{28,48}$ and the impact of strategies to mitigate such injury.

Author contributions Kyle Chin, Melina P. Cazorla-Bak, David F. Wilson, Sergei A. Vinogradov, Richard E. Gilbert, Kim A. Connelly, Roger G. Evans, Andrew J. Baker, C. David Mazer, and Gregory M.T. Hare contributed to all aspects of this manuscript, including study conception and design; acquisition, analysis, and interpretation of data; and drafting the article. Elaine Liu, Linda Nghiem, Yanling Zhang, and Julie $Y u$ contributed to the conception and design of the study, acquisition and interpretation of data, preparation of figures, and drafting the article.

\section{Disclosures None.}

Funding Support for this study was provided by the Innovation Fund, St. Michael's Hospital (to G.M.T. Hare), University of Toronto Merit Awards (to A.J. Baker, C.D. Mazer, K.A. Connelly and G.M.T. Hare). R.E. Gilbert holds a Canada Research Chair and this study was made possible by the Canada Research Chair's fund.

Editorial responsibility This submission was handled by Dr. Gregory L. Bryson, Deputy Editor-in-Chief, Canadian Journal of Anesthesia.

\section{References}

1. Hare GM, Tsui AK, Ozawa S, Shander A. Anaemia: can we define haemoglobin thresholds for impaired oxygen homeostasis and suggest new strategies for treatment? Best Pract Res Clin Anaesthesiol 2013; 27: 85-98.

2. Abrahamson JR, Read A, Chin K, et al. Renal tissue $\mathrm{PO}_{2}$ sensing during acute hemodilution is dependent on the diluent. Am J Physiol Regul Integr Comp Physiol 2020; 318: R799-812.

3. Eckardt KU, Koury ST, Tan CC, et al. Distribution of erythropoietin producing cells in rat kidneys during hypoxic hypoxia. Kidney Int 1993; 43: 815-23.

4. Koury ST, Koury MJ, Bondurant MC, Caro J, Graber SE. Quantitation of erythropoietin-producing cells in kidneys of mice by in situ hybridization: correlation with hematocrit, renal erythropoietin mRNA, and serum erythropoietin concentration. Blood 1989; 74: 645-51.

5. Johannes T, Mik EG, Nohe B, Unertl KE, Ince C. Acute decrease in renal microvascular $\mathrm{PO} 2$ during acute normovolemic hemodilution. Am J Physiol Renal Physiol 2007; 292: F796-803.

6. Lubbers $D W$, Baumgartl $H$. Heterogeneities and profiles of oxygen pressure in brain and kidney as examples of the pO2 distribution in the living tissue. Kidney Int 1997; 51: 372-80.

7. Rumsey WL, Abbott B, Lo LW, Vinogradov SA, Wilson DF. Imaging of oxygen distribution in the surface and deep areas of the kidney. Adv Exp Med Biol 1997; 411: 591-5.

8. Esipova TV, Barrett MJ, Erlebach E, Masunov AE, Weber B, Vinogradov SA. Oxyphor 2P: a high-performance probe for deeptissue longitudinal oxygen imaging. Cell Metab 2019; 29(73644): e7.

9. Wilson DF, Lee WM, Makonnen S, Finikova O, Apreleva $S$, Vinogradov $S A$. Oxygen pressures in the interstitial space and their relationship to those in the blood plasma in resting skeletal muscle. J Appl Physiol 1985; 2006(101): 1648-56.

10. Evans $R G$, Iguchi $N$, Cochrane $A D$, et al. Renal hemodynamics and oxygenation during experimental cardiopulmonary bypass in 
sheep under total intravenous anesthesia. Am J Physiol Regul Integr Comp Physiol 2020; 318: R206-13.

11. Evans RG, Smith DW, Lee CJ, Ngo JP, Gardiner BS. What Makes the Kidney Susceptible to Hypoxia? Anat Rec (Hoboken) 2019. DOI: https://doi.org/10.1002/ar.24260.

12. Gardiner BS, Smith DW, Lee CJ, Ngo JP, Evans RG. Renal oxygenation: from data to insight. Acta Physiol (Oxf) 2020. DOI: https://doi.org/10.1111/apha.13450.

13. Gerl K, Nolan KA, Karger $C$, et al. Erythropoietin production by PDGFR- $\beta(+)$ cells. Pflugers Arch 2016; 468: 1479-87.

14. Halperin ML, Cheema-Dhadli S, Lin SH, Kamel KS. Properties permitting the renal cortex to be the oxygen sensor for the release of erythropoietin: clinical implications. Clin J Am Soc Nephrol 2006; 1: 1049-53.

15. Esipova TV, Karagodov A, Miller J, Wilson DF, Busch TM, Vinogradov SA. Two new "protected" oxyphors for biological oximetry: properties and application in tumor imaging. Anal Chem 2011; 83: 8756-65.

16. Montero D, Lundby C. Arterial oxygen content regulates plasma erythropoietin independent of arterial oxygen tension: a blinded crossover study. Kidney Int 2019; 95: 173-7.

17. Pittman RN. Oxygen transport in the microcirculation and its regulation. Microcirculation 2013; 20: 117-37.

18. Olgac $U$, Kurtcuoglu $V$. Renal oxygenation: preglomerular vasculature is an unlikely contributor to renal oxygen shunting. Am J Physiol Renal Physiol 2015; 308: F671-88.

19. Lee CJ, Ngo JP, Kar S, Gardiner BS, Evans RG, Smith DW. A pseudo-three-dimensional model for quantification of oxygen diffusion from preglomerular arteries to renal tissue and renal venous blood. Am J Physiol Renal Physiol 2017; 313: F237-53.

20. Evans RG, Eppel GA, Anderson WP, Denton KM. Mechanisms underlying the differential control of blood flow in the renal medulla and cortex. J Hypertens 2004; 22: 1439-51.

21. Lee CJ, Gardiner BS, Evans RG, Smith $D W$. A model of oxygen transport in the rat renal medulla. Am J Physiol Renal Physiol 2018; 315: F1787-811.

22. Lee CJ, Gardiner BS, Ngo JP, Kar S, Evans RG, Smith DW. Accounting for oxygen in the renal cortex: a computational study of factors that predispose the cortex to hypoxia. Am J Physiol Renal Physiol 2017; 313: F218-36.

23. Lee CJ, Smith DW, Gardiner BS, Evans RG. Stimulation of erythropoietin release by hypoxia and hypoxemia: similar but different. Kidney Int 2019; 95: 23-5.

24. Wenger RH, Hoogewijs D. Regulated oxygen sensing by protein hydroxylation in renal erythropoietin-producing cells. Am J Physiol Renal Physiol 2010; 298: F1287-96.

25. Baumgärtl H, Leichtweiss HP, Lübbers DW, Weiss $C$, Huland $H$. The oxygen supply of the dog kidney: measurements of intrarenal pO 2. Microvas Res 1972; 4: 247-57.

26. Leichtweiss HP, Lübbers DW, Weiss C, Baumgärtl H, Reschke W. The oxygen supply of the rat kidney: measurements of int4arenal pO2. Pflugers Arch 1969; 309: 328-49.

27. Leonhardt $K O$, Landes $R R$. Oxygen tension of the urine and renal structures. Preliminary report of clinical findings. N Engl J Med 1963; 269: 115-21.

28. Zhu MZ, Martin A, Cochrane AD, et al. Urinary hypoxia: an intraoperative marker of risk of cardiac surgery-associated acute kidney injury. Nephrol Dial Transplant 2018; 33: 2191-201.

29. Iguchi N, Kosaka J, Iguchi Y, et al. Systemic haemodynamic, renal perfusion and renal oxygenation responses to changes in inspired oxygen fraction during total intravenous and volatile anesthesia. Br J Anaesth 2020; 125: 192-200.

30. Ash C, Dubec M, Donne K, Bashford T. Effect of wavelength and beam width on penetration in light-tissue interaction using computational methods. Lasers Med Sci 2017; 32: 1909-18.
31. Evans RG, Goddard D, Eppel GA, O'Connor PM. Factors that render the kidney susceptible to tissue hypoxia in hypoxemia. Am J Physiol Regul Integr Comp Physiol 2011; 300: R931-40.

32. Mistry N, Mazer CD, Sled JG, et al. Red blood cell antibodyinduced anemia causes differential degrees of tissue hypoxia in kidney and brain. Am J Physiol Regul Integr Comp Physiol 2018; 314: R611-22.

33. Weidemann A, Johnson RS. Nonrenal regulation of EPO synthesis. Kidney Int 2009; 75: 682-8.

34. Souma T, Suzuki N, Yamamoto M. Renal erythropoietinproducing cells in health and disease. Front Physiol 2015. DOI: https://doi.org/10.3389/fphys.2015.00167.

35. Kim N, Voicu L, Hare GM, et al. Response of the renal inner medulla to hypoxia: possible defense mechanisms. Nephron Physiol 2012; 121: 1-7.

36. Layton AT, Laghmani $K$, Vallon $V$, Edwards A. Solute transport and oxygen consumption along the nephrons: effects of $\mathrm{Na}+$ transport inhibitors. Am J Physiol Renal Physiol 2016; 311: F1217-29.

37. Ow CPC, Ngo JP, Ullah MM, Hilliard LM, Evans RG. Renal hypoxia in kidney disease: cause or consequence? Acta Physiol (Oxf) 2018. DOI: https://doi.org/10.1111/apha.12999.

38. Tsui AK, Marsden PA, Mazer CD, et al. Differential HIF and NOS responses to acute anemia: defining organ-specific hemoglobin thresholds for tissue hypoxia. Am J Physiol Regul Integr Comp Physiol 2014; 307: R13-25.

39. Beattie WS, Karkouti K, Wijeysundera DN, Tait G. Risk associated with preoperative anemia in noncardiac surgery: a single-center cohort study. Anesthesiology 2009; 110: 574-81.

40. Hare GM, Worrall JM, Baker AJ, Liu E, Sikich N, Mazer CD. Beta2 adrenergic antagonist inhibits cerebral cortical oxygen delivery after severe haemodilution in rats. Br J Anaesth 2006; 97: 617-23.

41. Hu T, Beattie WS, Mazer CD, et al. Treatment with a highly selective $\beta$-antagonist causes dose-dependent impairment of cerebral perfusion after hemodilution in rats. Anesth Analg 2013; 116: 649-62.

42. Ragoonanan TE, Beattie WS, Mazer CD, et al. Metoprolol reduces cerebral tissue oxygen tension after acute hemodilution in rats. Anesthesiology 2009; 111: 988-1000.

43. Ashes C, Judelman S, Wijeysundera DN, et al. Selective $\beta 1$ antagonism with bisoprolol is associated with fewer postoperative strokes than atenolol or metoprolol: a single-center cohort study of 44,092 consecutive patients. Anesthesiology 2013; 119: 777-87.

44. Hare GM, Mazer CD, Hutchison JS, et al. Severe hemodilutional anemia increases cerebral tissue injury following acute neurotrauma. J Appl Physiol 1985; 2007(103): 1021-9.

45. McCredie VA, Piva S, Santos M, et al. The impact of red blood cell transfusion on cerebral tissue oxygen saturation in severe traumatic brain injury. Neurocrit Care 2017; 26: 247-55.

46. Okonkwo DO, Shutter LA, Moore C, et al. Brain oxygen optimization in severe traumatic brain injury phase-II: a phase ii randomized trial. Crit Care Med 2017; 45: 1907-14.

47. Zarychanski R, Abou-Setta AM, Turgeon AF, et al. Association of hydroxyethyl starch administration with mortality and acute kidney injury in critically ill patients requiring volume resuscitation: a systematic review and meta-analysis. JAMA 2013; 309: 678-88.

48. Hare GM, Han K, Leshchyshyn Y, et al. Potential biomarkers of tissue hypoxia during acute hemodilutional anemia in cardiac surgery: a prospective study to assess tissue hypoxia as a mechanism of organ injury. Can J Anesth 2018; 65: 901-13.

Publisher's Note Springer Nature remains neutral with regard to jurisdictional claims in published maps and institutional affiliations. 